\title{
СТАНОВЛЕНИЕ ГЛОБАЛЬНОЙ ЭКОЛОГИЧЕСКОЙ ПОЛИТИКИ: ДОСТИЖЕНИЯ, ПРОМАХИ И РИСКИ
}

\begin{abstract}
Аннотация: Автор статьи рассматривает глобальную экологическую политику как систему политического управления экологической ситуацией и распределением природных ресурсов в глобальном масштабе, то есть с участием глобальных политических акторов и глобальным целеполаганием. В статье показаны основные этапы становления глобальной экополитики в ее нынешнем виде и системные истоки социально-политического конфликта, сопровождающего международно-политическую деятельность в природоохранной сфере. Высказывается мнение, что наблюдаемая неэффективность международной кооперации по поводу охраны окружающей среды является одним из следствий конщептуальной однобокости современной стратегии устойчивого развития, которая на практике допускает функиионирование иелого ряда соииально-экономических подсистем в рамках устаревшей модели неустойчивого развития. Несмотря на то, что организованная международная природоохранная деятельность возникла до появления концепции устойчивого развития, о так называемой устойчивой экополитике имеет смысл говорить лишь в контексте комплексной стратегии цивилизационного перехода на рельсы устойчивого развития, которая определяет ее фундаментальные принципы и содержание. Review: The author evaluates the global environmental policy as a system of political management of environmental situation and global allocation of natural resources with the participation of global political actors and global goalsetting. The article shows the key stages of the formation of global environmental policy in its current forms, as well as the systemic roots of the social and political conflict regarding the international political activities in the environmental sphere. The author expresses an opinion that the lack of efficient international cooperation on environment protection issues is due to the conceptual lop-sidedness of the modern sustainable development strategy, since in practice it allows for the functioning of a range of social and economic sub-systems within the frameworks of outdated models of non-sustainable development. In spite of the fact that organized international environmental activity was formed before the concept of sustainable development, one may discuss the so-called sustainable environmental policy within the framework of a complex strategy of civilization transfer to sustainable development, defining its fundamental principles and contents.
\end{abstract}

Ключевые слова: Экологическая политика, устойчивое развитие, глобальные проблемы, энвайронментализм, глобальное развитие, соичиориродная справедливость, устойчивая экополитика, климатический скептицизм, охрана окружающей среды, политическая модель УР

Keywords: environmental policy, sustainable development, global problems, environmentalism, global development, social environmental justice, sustainable environmental policy, climatic skepticism, environment protection, political model of sustainable development.

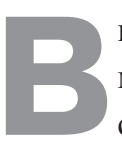

июне 1992 года в Рио-де-Жанейро прошла знаменитая Конференция ООН по окружающей среде и развитию, которая констатировала, что человечество переживает решающий момент в истории: противоречия между характером развития цивилизации и природой достигли предела, и даль- нейшее движение по этому пути ведет к глобальной экологической катастрофе. Произошло осознание планетарного характера угроз и опасностей, нависших над человечеством в связи со сложившейся системой сверхпотребления постиндустриального меньшинства и реальной угрозой омницида. Современная модель 
DOI: 10.7256/1811-9018.2013.9.9216

При цитировании этой статьи сноска на dоі обязательна

Человек и окружающая среда

цивилизационного развития была признана моделью неустойчивого развития, и все государства-члены ООН приняли беспрецедентное решение изменить опасный курс, приняв в итоговом документе «Повестка дня на 21 век» программу реализации устойчивого развития.

C конца XX века концепция устойчивого развития находится в центре научного (как междисциплинарного, так и отраслевого) и политикопрактического интереса в России и за рубежом. За прошедшие 20 лет стратегии или программы УР приняли более 100 стран (в том числе и Россия - на уровне концепции перехода к УР).

Однако, исходя из результатов динамики глобальной экологической ситуации, можно сделать вывод, что принципы УР не удалось полностью внедрить ни в одной стране мира. Попытки принять стратегию устойчивого развития без отказа от прежних установок привели к системному сопротивлению действующих институтов всех уровней полноценной интеграции целей УР как функциональных принципов их работы. Это, в свою очередь, привело к возникновению «двойных стандартов» или параллельных тенденций во многих областях. Так, например, сфера экономического и финансового управления, как на национальном, так и на международном уровне, осталась за пределами компетенции УР. Независимо от УР продолжают существовать и теория и практика развития, несмотря на политические декларации. Национальные советы по УР и другие подобные институты ни в одной стране мира не достигли того политического веса, чтобы реально влиять на бюджетную политику государства, в отличие от крупнейших бизнес-структур, функционирующих в традиционной экономоцентричной системе.

Становление концепции УР самым непосредственным образом связано с эволюцией восприятия глобальной экологической проблематики. Анализ становления глобальной экологической политики, хотя и сфокусирован на экологическом измерении УР (которым оно, безусловно, не может исчерпываться), позволяет достаточно легко выявить те болевые точки международной кооперации, которые образуются в местах «состыковки» экологических установок с глобальными социальноэкономической и этической подсистемами. Этот анализ проливает свет на суть конфликта, или концептуального упущения, который свойственен современной политической модели УР.
Экология стала более или менее заметным политическим фактором только в 60-х годах XX века. С тех пор правительства, НПО и другие акторы регулярно предпринимают попытки найти эффективные формы решения экологических проблем на разных уровнях. Некоторые соглашения, принятые и принимаемые в этой сфере, разрабатываются в рамках классических методов международных переговоров или политического управления, в то время как все явственнее проявляет себя тенденция к поиску новой, «прорывной» технологии достижения политических соглашений в этой области.

Первоначально проблема окружающей среды не выходила за рамки внутригосударственной повестки. Истоки так называемого энвайронментализма связывают, в первую очередь, с рядом объективных факторов, а именно целой серией техногенных катастроф, произошедших в различных странах. Экологическая катастрофа в Японии, вызванная промышленным загрязнением ртутью бухты Минамата, загрязнение нефтью Великих Озер в США и другие опасные «симптомы» надвигающейся экологической катастрофы спровоцировали появление национальных экологических движений, которые, в свою очередь, стали способствовать дальнейшему росту озабоченности глобальными экологическими вызовами. Серьезным толчком к осознанию глобального биосферного неблагополучия послужило появление ядерного оружия в конце Второй мировой войны. С последним связан первый удачный опыт сотрудничества ученых в послевоенном мире - возникновение Международного Пагуошского движения ученых, выступавших за мир, разоружение, безопасность и научное сотрудничество.

Нелишним будет отметить, что имеют место и иные подходы к определению социально-экономических и политических предпосылок актуализации природоохранной проблематики в общественном сознании. Так, например, в 1970-х гг. американский исследователь в области истории экологического движения Р. Нэш провел исторический анализ энвайронменталистских течений в США и условий возникновения разнообразных экологических организаций ${ }^{1}$. Ученый пришел к выводу, что энвайронментализм, или (в его интерпретации) формирование восприятия дикой природы как чего-то прекрасного и нуждающегося в защите, было в известной степени результатом

\footnotetext{
${ }^{1}$ Nash R. Wilderness and the American mind. New Haven, 1973.
} 
DOI: 10.7256/1811-9018.2013.9.9216

При цитировании этой статьи сноска на dоі обязательна

\section{Право и политика 9 (165) • 2013}

внутрисоциальных процессов, таких как урбанизация и индустриализация. К примеру, появление таких известных в США экологических организаций как Сьерра Клуб (1892) и Национальное Одюбоновское общество (1905) совпадает по времени с пиком индустриализации и урбанизации в Северной Америке. Нэш приходит к выводу, что более материально обеспеченные слои населения и представители среднего класса в большей степени склонны воспринимать дикую природу как ценность и как объект защиты, чем представители низших слоев населения (рабочего класса) $)^{2}$. Э. Гидденс, в свою очередь, связывает возникновение энвайронменталистских течений в наиболее развитых обществах с нарастающим ощущением разрыва с традицией, или корнями, что было вызвано переменой условий труда, покиданием родных жилищ и появлением многочисленных социальных ролей, которые вынужден исполнять современный член социума $^{3}$. Таким образом, ученые небезосновательно полагают, что наиболее ярые адепты энвайронментализма могут происходить лишь из материально успешных слоев общества, но отнюдь не из всех классов и не на всех уровнях социального развития. Эти тенденции имеют принципиальное значение для политического измерения глобальных экологических проблем, так как указывают на то, что разные слои общества и даже страны способны проявлять неодинаковый уровень экологической сознательности.

Одним из первых государств, принявших законодательные акты по охране атмосферы, была Великобритания - в 1956 г. Уже в 1970-е гг. многие государства начинают у себя создавать специальные министерства и другие ведомства по охране окружающей среды. Если в 1972 г. такие структуры были в 26 странах, то в начале 1980 -х гг. - уже в $144^{4}$. Не в последнюю очередь, критические изменения окружающей природной среды и пагубное воздействие на нее человеческой деятельности стали предметом глобального осмысления благодаря огромному накопленному объему научного материала. В 1960-е годы стали появляться авторитетные труды о проблемах

\footnotetext{
${ }^{2}$ Forsyth T. Global environmental problems and politics: Undergraduate study in Economics, Management, Finance and the Social Sciences. London, 2011.

${ }^{3}$ Giddens A. Beyond Left and Right: the future of radical politics. Cambridge, 1994.

${ }^{4}$ Дробот Г.А. Мировая политика как феномен глобального мира: учебное пособие. М., 2010. С.462.
} 1184

(C) NOTA BENE (ОOО «НБ-Медиа») www.nbpublish.com окружающей среды, среди которых - знаменитая книга Р. Карсон «Молчаливая весна» (1962), посвященная возможным последствиям влияния пестицидов на экосистемы. Важную роль в процессах комплексного осмысления нарастающих угроз сыграл Римский клуб, получивший широкую известность благодаря выполненным по его заказам исследованиям (докладам Римскому клубу) в рамках того направления науки, которое в дальнейшем получило наименование глобальных исследований, а в России - глобалистики. Исследования, инициированные Римским клубом, подготовили почву для организации обсуждения проблем глобального развития на межгосударственной основе в рамках $\mathrm{OOH}$, где и был впервые вынесен на повестку дня вопрос о необходимости поиска новой модели развития цивилизации.

В 1972 году ООН провела в Стокгольме первую конференцию, посвященную проблемам окружающей среды. Она вошла в историю как «Саммит Земли». Стокгольмская встреча стала очень значимым событиям по ряду причин. Принципиальным вопросом, поднятым на ней, стала сама идентификация «глобальных» экологических проблем как универсальных и разделяемых всеми без исключения. Тогда не только впервые было заявлено о включении в программы действий на правительственном уровне мер для решения проблем деградации окружающей природной среды, но и сформулирован важный принцип международного сотрудничества и необходимости принятия коллективных мер для решения глобальной экологической проблемы. Книга, подготовленная биологом Р. Дюбо и экономистом Б. Вардом по итогам конференции, носила название «Только одна Земля», которое отражало установку на учет глобальных ограничений - ведь у нас лишь одна планета.

Неслучайно время проведения Конференции совпало и с публикацией первого доклада Римскому клубу - «Пределы роста». Речь идет о представленных в 1972 году результатах исследования «Сложное положение человечества», проведенного группой ученых под общей редакцией Денниса и Донеллы Медоуз 5 . Ученые предсказали достаточно скорый коллапс производства и резкое снижение материальных стандартов жизни, если объемы потребления материальных ресурсов останутся без изменений. С рядом оговорок можно сказать, что на ближайшие десять лет в научном и международно-политическом дискурсе закрепился ${ }^{5}$ Meadows, Donella H., Meadows, Dennis L., Randers Jorgen. Beyond
the Limits. London, 1985. P. 133, 199. 
DOI: $10.7256 / 1811-9018.2013 .9 .9216$

При цитировании этой статьи сноска на dоі обязательна

Человек и окружающая среда

так называемый «ресурсный» подход к решению глобальных экологических проблем.

Между тем, следует признать, что в ходе Стокгольмской конференции стали очевидными некоторые классические разграничительные линии между богатыми и беднейшими странами. Так, например, в ходе дебатов известную политическую ангажированность проявило правительство США, которое яростно настаивало на запрете охоты на китов и других действий, ставящих под угрозу исчезающие виды животных, но при этом всячески сопротивлялось попыткам представителей ряда стран ввести ограничения на промышленное загрязнение или запрет на испытание ядерного оружия. СССР вообще бойкотировал конференцию. Наиболее знаменательным событием встречи в Стокгольме стала речь премьер-министра Индии И. Ганди, которая заявила о том, что самой серьезной экологической проблемой является «бедность». Оратор попыталась призвать богатые страны оказать помощь беднейшим государствам, таким как Индия, чтобы те, ускорив свое развитие, могли лучше справляться с экологическими вызовами. Речь И. Ганди заложила основу для дальнейших дискуссий вокруг вопроса об ответственности развитых и развивающихся стран друг перед другом и за глобальные экологические проблемы. Основным выводом, к которому подталкивал характер развернувшейся в Стокгольме дискуссии, было резкое разделение мира на богатых и бедных с различными экологическими ценностями. И в этом смысле - в социальном ракурсе - планета оказывалась далеко не «единой».

Следует отметить также еще одно принципиальное «достижение» конференции в Стокгольме, встречающее неоднозначные трактовки в свете обострившихся в последующие десятилетия противоречий. В 1972 году были фактически утверждены принцип уважения суверенитета и суверенное право на развитие в экологической международно-политической плоскости. В соответствии с Принципом 21-м Стокгольмской декларации, «государства имеют суверенное право разрабатывать свои собственные ресурсы согласно своей политике в области окружающей среды и несут ответственность за обеспечение того, чтобы деятельность в рамках их юрисдикции или контроля не наносила ущерба окружающей среде других государств или районов за пределами действия национальной юрисдикции» ${ }^{6}$. Данное положение в сущ-

\footnotetext{
${ }^{6}$ Стокгольмская Декларация// Общественный экологический Internet-проект EcoLife. URL: http://www.ecolife.org.ua/laws/ inter/1972/04.php.
}

ности подвело юридическую базу под фундаментальное когнитивное противоречие, сопровождающее глобальную политику со времен ее фактического зарождения по настоящее время, а именно - противоречие между осознанными и охраняемыми суверенными правами национальных акторов международной политики и целостностью, неделимостью биосферы, по поводу охраны которой эта международная политика имеет место.

Тем временем к 1980-м годам стало очевидно, что необходим новый подход к выстраиванию глобальноэкополитической повестки дня. Катастрофа, предсказанная в книге «Пределы роста», не произошла. И на смену пессимизму 70-х в 1980-х гг. пришла вера во всемогущие силы рынка, что нашло отражение в основных политических событиях этого периода, оказавших влияние на поиски путей решения экологических проблем.

Уже в 1982 году правительство Великобритании стало все чаще использовать термин «устойчивость» как характеристику «разумной» экономической экспансии, а не природопользования. В этой связи известный экоактивист Мохамед Идрис в начале 1990-х годов заявил о фактическом существовании двух подходов к определению «устойчивости». С экологической точки зрения, «устойчивое» подразумевает сохранение и поддержание целостности экосферы, гармоничные отношения между человеком и природой. Неэкологическая трактовка термина «устойчивость» сводится как ответу на вопрос, как бесконечно обеспечивать доступ к сырью в условиях, когда запасы этого сырья истекают?ㄱ. В 1990 году один из спикеров на симпозиуме ОЭСР довольно метко охарактеризовал степень поглощения природоохранной повестки экономикой роста: «Эволюцию отношения к экологическим проблемам за последние двадцать лет можно проследить по тому, как они «переместились» с последней страницы ведущих газет на главные и далее - в финансовые рубрики» ${ }^{8}$.

В конце 1980-х гг. отмечается рост международной активности по заключению многосторонних соглашений в природоохранной сфере. Например, в 1985 году была подписана Венская конвенция (а в 1987 - Монреальский протокол), включившая законодательно закрепленные нормы выбросов озоноразрушающих веществ.

\footnotetext{
${ }^{7}$ Цит. по: Beder Sh. The Hidden Messages Within Sustainable Development// Social Alternatives, vol.13, no. 2, July 1994.

${ }^{8}$ Там же.
} 
DOI: 10.7256/1811-9018.2013.9.9216

При цитировании этой статьи сноска на доі обязательна

\section{Право и политика 9 (165) • 2013}

Поистине историческим событием, оказавшим принципиальное влияние на осмысление и дальнейшее развитие глобальной экологической политики, стал созыв в 1983 году Всемирной Комиссии по проблемам окружающей среды и развития (МКОСР), известной по имени ее председателя - премьер-министра Норвегии Гру Харлем Брундтланд (Комиссия Брундтланд). Комиссия представляла собой серию встреч экспертов и представителей из разных стран, как богатых, так и бедных. В 1987 году под эгидой МКОСР вышел доклад «Наше общее будущее», который представил ряд рекомендаций по тому, как одновременно совмещать экономический рост и охрану окружающей среды, что существенно отличало его от «Пределов роста». Этому докладу обязано своим происхождением самое известное определение понятия устойчивого развития как такого развития, при котором «удовлетворение потребностей настоящего времени не подрывает способность будущих поколений удовлетворять свои собственные потребности»9. Данное определение подразумевает право развивающихся стран на дальнейший экономический рост, но при этом подтверждает тезис о том, что быстрое промышленное развитие и рост способны нанести больше вреда, чем пользы. В то же время было ясно, что предложенное определение слишком обще и, как следствие, вызывает много вопросов. Некоторые из них озвучил М. Редклифт в своем труде: «Устойчивое развитие: исследуя противоречия» $(1987)^{10}$. Редклифт, в частности, акцентировал внимание на отсутствии единства трактовки самого содержания устойчивого развития - проблеме, которая с тех пор неоднократно звучала в политико-экологическом дискурсе. В то время как многие развитые страны ставят во главу угла чаяния будущих поколений (пытаются ответить на вопрос, в какой мере и каким образом нынешний тип развития может повлиять на жизнь будущих поколений), большинство развивающихся стран проявляют большую озабоченность «горизонтальным» неравенством (неравными возможностями стран в плане адаптации к переменам или отстаивания собственных политических ценностей). Вместе с тем, следует отдать должное этому исторически первому определению понятия УР, которое фактом своего появления уже означало масштабный мировоззренческий

${ }^{9}$ WCED (World Commission on Environment and Development) Our common future. URL: http://www.un-documents.net/ocf-02.htm

${ }^{10}$ Redclift $M$. Sustainable development: exploring the contradictions. London, 1987. прорыв. Было вполне осознано, что хоть сколько-нибудь работоспособная глобальная стратегия развития не может исключать фактора экономического роста, который, в свою очередь, подразумевает повышение уровня образования и здоровья населения планеты, что в очередной раз и с новой силой актуализировало вопрос о необходимости оказания материальной и технологической помощи беднейшим странам.

Основным событием 1990-х гг. стал Саммит Земли (Конференция ООН по окружающей среде и развитию), прошедший в Рио-де-Жанейро в 1992 году. На этой конференции были впервые в истории приняты юридически и политически обязывающие соглашения между странами в области изменения климата и биоразнообразия. Конференция констатировала, что человечество переживает решающий момент в истории: противоречия между сложившимся характером развития цивилизации и природой достигли предела, и дальнейшее движение по этому пути ведет к глобальной экологической катастрофе. Произошло осознание планетарного характера угроз и опасностей, нависших над человечеством в связи со сложившейся системой сверхпотребления постиндустриального меньшинства и реальной угрозы омницида. Программа реализации устойчивого развития нашла отражение в итоговом документе - «Повестка дня на 21 век».

Между тем обсуждение экологических вызовов на этой конференции опять-таки зачастую сводилось к спору по поводу конкретных экономических и политических интересов отдельных государств. Дискуссия развернулась вокруг степени участия развитых и развивающихся стран в создании парникового эффекта. Так, например, в планах инициаторов Саммита изначально стояло подписание третьего соглашения по защите лесов, но это предложение было в итоге отвергнуто основными странами, на территории которых расположены тропические леса (особенно Бразилией, Индонезией и Малайзией). Оно было воспринято как угроза ограничения их прав на те ресурсы, которыми богатые страны уже успели воспользоваться ${ }^{11}$.

В 2002 году в Йоханнесбурге (ЮАР) прошла еще одна крупная конференция $\mathrm{OOH}$, посвященная глобальным экологическим проблемам и развитию Всемирный саммит $\mathrm{OOH}$ по устойчивому развитию (ВСУР, или «РИО+10»), где 191 стран - членов ООН

\footnotetext{
${ }^{11}$ Forsyth $T$. Global environmental problems and politics: Undergraduate study in Economics, Management, Finance and the Social Sciences. London, 2011.
} 
DOI: 10.7256/1811-9018.2013.9.9216

При цитировании этой статьи сноска на dоі обязательна

Человек и окружающая среда

выразили приверженность новой форме цивилизационного развития, установив конкретные сроки такого перехода и обсудив конкретные механизмы принятия решений. В «Плане выполнения решений Всемирной встречи на высшем уровне по устойчивому развитию» (План действий) предпринята попытка системного анализа проблемы и построения политического алгоритма действий ${ }^{12}$. Встреча в Йоханнесбурге примечательна, в первую очередь, тем, что на ней основное внимание было уделено проблемам беднейших государств, таким как крайняя нищета и нехватка питьевой воды.

На саммите также обсуждались возможные новые формы управления, которые бы позволили государствам и негосударственным акторам (бизнесу и крупным НПО), вступив в партнерские отношения, более эффективно проводить природоохранную политику на местном уровне, а не множить международные соглашения по отдельным пунктам экологической повестки.

Наконец, в июне 2012 года в Рио-де-Жанейро прошла Конференция ООН по устойчивому развитию «Рио+20». В саммите, который стал самым большим мероприятием в истории ООН, приняли участие более 45 тысяч человек, в том числе 12 тысяч делегатов из 188 стран, почти 10 тысяч представителей общественных организаций и 4 тысячи журналистов. В общей сложности правительства стран, бизнес, общественные организации и университеты представили более 690 новых целей и проектов в сфере устойчивого развития и «зеленой» экономики.

При этом результаты саммита повсеместно были признаны неоднозначными. Организация ООН по окружающей среде (ЮНЕП) накануне саммита опубликовала «Резюме для политиков и лиц, принимающих решения» - доклад «Geo-5 (Глобальная экологическая перспектива)», в котором констатировала полный провал намеченного 20 лет назад плана УР, из 90 пунктов которого только четыре получили положительную оценку ${ }^{13}$. Многие организации, занимающиеся вопросами развития человечества и защиты окружающей среды, уже после

12 План выполнения решений Всемирной встречи на высшем уровне по устойчивому развитию// Официальный сайт OOH. URL: http://www.un.org/russian/conferen/wssd/docs/plan_wssd.pdf

${ }^{13}$ Доклад «Geo-5» «Резюме для политиков и лиц, принимающих решения»// Официальный сайт «Гражданской Двадцатки (C20)». URL: http://www.g20civil.com/upload/iblock/f65/GEO-5_SPM_Russian.pdf конференции заявили, что финальное соглашение, достигнутое на «Рио +20» («Будущее, которое мы хотим»), и меры, которые предлагаются, являются слишком слабыми, чтобы преодолеть надвигающийся социальный и экологический кризис. Так, например, были безрезультатными попытки ликвидировать субсидии на добычу ископаемого топлива. Были существенно снижены планы по обеспечению бедных слоев населения чистой водой, надлежащим питанием и современными энергоисточниками. В связи с предстоящими на тот момент выборами в США и финансовой неопределенностью в еврозоне, меры оказания финансовой помощи развивающимся странам для перехода к «зеленой» экономике были заблокированы. Как сообщали СМИ, по каждой странице финального документа шли дипломатические баталии. Евросоюз настаивал на природоохранном приоритете, а развивающиеся страны хотели закрепить обязательства развитых держав в отношении финансово-технологической помощи их развитию.

Даже после такого достаточно беглого экскурса в историю глобальной экологической политики становится очевидным целый ряд ее системных проблем и изъянов. Политическое измерение многочисленных дискуссий в области экологической деятельности состоит в вопросе о том, как разные взгляды на проблему деградации окружающей среды влияют на выбор политической стратегии ее разрешения.

Во-первых, многие развивающиеся страны скептически относятся к той озабоченности, которую проявляют экономически успешные соседи по отношению к проблемам окружающей среды, что неоднократно проявлялось на дискуссионных площадках международных форумов, посвященных проблемам окружающей среды. Почему развивающиеся страны, которые испытывают колоссальные экономические и социальные трудности, должны брать на себя ответственность за глобальные экологические проблемы?.. Почему первым делом они должны решать вопросы охраны окружающей среды, а не собственного развития?.. Ведь в ряде случаев, таких например, как обезлесение и индустриализация, богатые страны исторически дольше, чем развивающиеся страны, способствовали возникновению глобальных проблем, поэтому им кажется несправедливым «перекладывание» на них всей ответственности. По мнению индийской писательницы и экоактивистки В. Шивы, многие противоречия в международной экологической политике проистекают 
DOI: 10.7256/1811-9018.2013.9.9216

При цитировании этой статьи сноска на dоі обязательна

\section{Право и политика 9 (165) • 2013}

из глобальной социально-экономической дифференциации, в основе которой лежит дихотомия «Север-Юг».

Многие исследователи, в том числе западные, видят основное препятствие на пути реализации эффективной глобальной экологической политики в том, что развитые страны не выполняют данных бедным странам обещаний по оказанию им помощи в экономическом развитии. В результате развивающиеся страны начинают опасаться, не подменяет ли «навязываемая» им внешняя помощь в решении экологических проблем принятых ранее обязательств по содействию в развитии. Кроме того, такая ситуация порождает подозрение у беднейших стран, что заключаемые соглашения в области охраны окружающей среды - это лишь очередной инструмент сдерживания их экономического роста, применяемый с целью не допустить их превращения в конкурентоспособных игроков на глобальном рынке ${ }^{14}$. Развитые страны действительно неохотно делятся своими технологиями с развивающимися соседями, а многие из них вообще сопротивляются включению этих стран в международную торговлю. Как следствие, развивающиеся страны часто предпочитают устраняться от активного участия в решении глобальных экологических проблем.

Одним из последствий этой дихотомии, или даже инструментом недопущения достижения опасного, с точки зрения наиболее уязвимых акторов, консенсуса по подходам к решению проблем окружающей среды стал так называемый «экологический релятивизм». Несмотря на декларируемое еще со времен конференции в Стокгольме признание экологических проблем как «универсальных», «общечеловеческих», зачастую подходы не только к их решению, но даже самой постановке этих проблем формируются в зависимости от региональной социально-экономической и политической конъюнктуры. В результате страны начинают «исповедовать» различные экологические ценности, что не только лишает глобальную экологическую проблематику организационной и содержательной логики, но и ставит под вопрос саму возможность решения глобальных экологических проблем. В качестве иллюстративного примера таких противоречий можно привести бурную дискуссию, развернувшуюся в начале 1990-х гг. между американским Институтом мировых ресурсов (WRI) и индийским Центром на-

\footnotetext{
${ }^{14}$ Anderson $J$. W. The International Politics of Sustainable Development// Resources For the Future. Washington, 2002. URL: http://www. rff.org/rff/Documents/RFF-IB-02-15.pdf
}

уки и окружающей среды (CSE) $)^{15}$. В 1990 году WRI опубликовал один из первых докладов, посвященных проблеме распределения ответственности между различными странами за выбросы парниковых газов. Доклад был в достаточной степени политизирован. В нем для расчетов применялся индекс, который основывался главным образом на показателях дефорестации и предполагаемых объемов выбросов метана от рисовых плантаций и скота. В результате в первую шестерку стран - лидеров по выбросам парниковых газов в атмосферу попали Бразилия, Индия и Китай. Публикация доклада вызвала бурю негодования среди развивающихся стран. В частности CSE выступил с заявлением о том, что доклад WRI основывается на государственной статистике, а не на расчетах объема выбросов на душу населения, по которым развитые страны, разумеется, существенно превышают развивающиеся. Во-вторых, в основу индекса брались упрощенные оценки обезлесения и выбросов метана. Кроме того, не был учтен различный характер причин обезлесения в разных регионах планеты. Деградация лесов могла стать следствием увеличения производства продуктов питания для бедных слоев населения, что с этических позиций не позволяет ставить ее в один ряд с другими возможными причинами дефорестации. И, возможно, самым главным недостатком этого доклада было то, что примененный в нем индекс никоим образом не рассматривал исторический аспект дефорестации и индустриализации в развитых странах (парниковые газы присутствуют в атмосфере уже много лет). Таким образом, с одной стороны, приведенный доклад WRI был предельно точен в определении современных источников парниковых газов и степени ответственности за их выбросы тех или иных государств. В то же время его авторы сделали ряд допущений, которые обнаруживают в себе достаточно упрощенный подход к объяснению природы повышения концентрации парниковых газов в атмосфере и процессов обезлесения. Эти его недостатки дали основательную почву для критики, которая в своей наиболее радикальной форме доходила до того, что некоторые скептики усматривали в докладе WRI политический документ, преследующий цель ограничить право развивающихся стран пользоваться собственными ресурсами.

\footnotetext{
${ }^{15}$ Forsyth T. Global environmental problems and politics: Undergraduate study in Economics, Management, Finance and the Social Sciences. London, 2011.
} 
DOI: $10.7256 / 1811-9018.2013 .9 .9216$

При цитировании этой статьи сноска на dоі обязательна

Человек и окружающая среда

Решение данной проблемы в достаточной степени осложнено тем, что в ней, как уже отмечалось выше, помимо социально-экономической и собственно экологической, присутствует сильная моральноэтическая составляющая. Например, А. Агарвал и С. Нараян в своей книге «Глобальное потепление в неравном мире» настаивают на введении разграничения между «эмиссией роскоши» (производства товаров роскоши и обеспечения высокого уровня жизни) и «эмиссией выживания» (производства продовольствия или, например, натурального хозяйства $)^{16}$. Как пишет А. В. Прокофьев, «в некоторых случаях - следствием сокращения вредных выбросов или снижения их роста будет лишь незначительное уменьшение довольно высокого уровня жизни или даже его консервация, в других - coxранение массовой нищеты и высокой смертности» ${ }^{17}$.

Во-вторых, обширное поле для политического манипулирования экологической проблематикой не в последнюю очередь предоставляет и та принципиальная неопределенность, которая свойственна естественно-научным подходам к формулированию глобальных экологических проблем, становясь источником политических и околонаучных спекуляций.

Репутация одной из самых политизированных тем экологической повестки принадлежит проблеме изменения климата. Так, по мнению одних «климатических скептиков», зависимость глобальных климатических изменений от уровня углекислого газа не очевидна, а исторические тенденции в течение геологических периодов таковы, что Землю ждет скорее остывание, чем потепление. Ряд ученых склонны объяснять текущие изменения климата колебаниями получаемого Землей количества солнечной энергии, циклами Миланковича, а не антропогенной деятельностью. Другие вообще настаивают на принципиальной неизученности природы изменений солнечной радиации и, как следствие, некорректности попыток ее объяснения исходя из текущих трендов.

В 2007 году Межправительственная группа экспертов по изменению климата презентовала Четвертый оценочный доклад, в котором утверждается, что ожидаемое удвоение концентрации углекислого

${ }^{16}$ Agarwal A., Narain S. Global warming in an unequal world. New Delhi, 1991.

${ }^{17}$ Прокофьев А. В. Климатическая справедливость: российский контекст. URL: http://iph.ras.ru/uplfile/root/biblio/em/em11/7.pdf газа в атмосфере по сравнению с доиндустриальной эпохой должно привести к повышению температуры нашей планеты до $2-4,5^{\circ} \mathrm{C}$. С тех пор климатологискептики (Т. Бернтсен, Р. Линдзен и др.) неоднократно публиковали собственные расчеты корреляции между растущей концентрацией углекислого газа и ростом среднепланетарной температуры, доказывающие, что данные оценки сильно завышены.

Энвайронменталисты, в свою очередь, обвиняют скептиков в потакании интересам нефтяной и угольной промышленности, которые, по их мнению, преследуют цель всячески обесценить научную работу в области изменений климата, финансируя соответствующие исследования и пропаганду.

Первым глобальным соглашением об охране окружающей среды, основанным на рыночном механизме регулирования, стал принятый в 1999 году Киотский протокол, использующий механизм международной торговли квотами на выбросы парниковых газов. Научный и политический скептицизм с самого начала сопровождал работу над Протоколом (его авторов, в частности, обвиняют в «схематической наукообразности»), но первым серьезным политическим актом, поставившим под вопрос смысл всей дальнейшей работы над проектом, стал, как известно, выход из него в 2001 году США, на чью долю приходится $25-35 \%$ (по разным оценкам) выбросов в мире. Вашингтон мотивировал свое решение тем, что это нанесет ущерб национальной экономике. Хотя в декабре 2012 года по итогам переговоров в Дохе действие Киотского протокола было продлено до 2020 года, упомянутые переговоры проходили в довольно напряженной обстановке. Крупные производители парниковых газов - США, страны Евросоюза и Китай - приняли договоренности с различными оговорками, а малые островные государства выразили откровенное разочарование достигнутыми результатами.

Еще одной особенностью современной системы принятия международных политических решений в области экологии, на которой хотелось бы заострить внимание, является ее архаичность и государствоцентризм, что, в частности, проявляется в доминировании тех или иных государств в процессе выработки решений по глобальным экологическим проблемам. С одной стороны, это выглядит достаточно логично и обуславливается той ролью, которую то или иное государство сыграло в ухудшении экологической обстановки. Например, США по праву играют пер- 
DOI: 10.7256/1811-9018.2013.9.9216

При цитировании этой статьи сноска на dоі обязательна

\section{Право и политика 9 (165) • 2013}

вую скрипку в формулировании и решении проблемы глобальных климатических изменений, так как являются одним из рекордсменов по выбросам парниковых газов, а также по объему международных инвестиций. При этом, в деле решения проблем тропических лесов влияние США гораздо меньше, чем, например, Бразилии, на территории которой, в силу ее географических особенностей, расположено около $41 \%$ общей площади тропических лесов планеты. По этому вопросу Бразилия по естественно-географическим причинам занимает доминирующее положение в международной системе. И хотя, как известно, тот или иной международный режим может быть установлен и без участия такого «гегемона» (например, Киотский протокол в 2005 году вошел в силу, несмотря на отказ от участия в нем США), в краткосрочной перспективе он вряд ли способен серьезно повлиять на ситуацию. С другой стороны, зачастую степень влияния на формирование глобальной экологической политики напрямую зависит от международного авторитета данного государства, его военной мощи, площади территории, вклада в мировую торговлю, численности населения, одним словом - от его внешнеполитического ресурса, понимаемого в терминах классической парадигмы международной политики.

Кроме того, глобальная экологическая политика по определению не может быть частным делом отдельных государств. В последние десятилетия заметно возросла роль негосударственных акторов, то есть тех политических субъектов, которые не связаны напрямую с конкретными национальными государствами. В свою очередь, роль государств (в таких областях, как инвестиции или развитие инфраструктуры) стремительно сокращается, и частный бизнес зачастую располагает большими возможностями для экономической деятельности на местном уровне, особенно в беднейших странах. Усилия по формированию устойчивого будущего предполагают комплексный подход к деятельности в основном в трех ключевых областях - экономике, социальной сфере и экологии. В терминах акторности это означает как техническое взаимодействие акторов с соответствующей специализацией, так и их общее целеполагание и приверженность единым принципам - принципам УР. Глобальная повестка формируется не только «сверху», но также «снизу» и «извне», что в перспективе станет принципиальной предпосылкой перехода к УР. Эти процессы являются естественным следствием развития и роста числа каналов коммуни- кации и взаимовлияния. Накапливая свое информационное содержание, глобально-политическая система развивается и усложняется. Это объективный процесс и его недоучет чреват глобальными негативными последствиями, и уже не только политическими, но и социоприродными, приближая глобальную антропоэкологическую катастрофу.

Отдельного внимания заслуживает вопрос эффективности национальной экологической политики стран, интегрированных в международный диалог по поводу поиска путей выхода из глобального экологического кризиса. С одной стороны, проблемы, возникающие на этом уровне, являются следствием противоречивой и непоследовательной международной политической практики в этой сфере. С другой стороны, национальный уровень в силу объективно-исторических, культурно-цивилизационных и географических условий обладал, обладает и, видимо, будет обладать в дальнейшем известной степенью автономности. Кроме того, отдельные национальные государства, как «единицы коллективного самоопределения и самостоятельные распределительные системы» ${ }^{18}$, подобно увеличительному стеклу демонстрируют те концептуальные противоречия и технические трудности реализации экологической политики (тем более - политики УР), которые во многом обуславливаются несовершенством глобальной экологической кооперации.

Во-первых, вплоть до настоящего времени меры по уменьшению негативного воздействия антропогенной деятельности на экосистему, предпринимаемые правительствами на разных уровнях, сосредоточены на технологической модернизации. Это обусловлено объективными трудностями в постановке и популяризации в сущности непопулярных с традиционно-политической точки зрения целей, связанных с любыми формами контроля численности населения или прироста его благосостояния. Однако, как справедливо отмечают авторы доклада «Назад к нашему общему Будущему» («Back to our common Future»), подготовленного к Саммиту Земли 2012 года, только посредством технологических новшеств никогда не удавалось нивелировать негативные эффекты антропогенной деятельности, связанные с бесконтрольным наращиванием материальных богатств при растущей численности населения.

\footnotetext{
${ }^{18}$ Прокофьев A. В. Климатическая справедливость: российский контекст. URL: http://iph.ras.ru/uplfile/root/biblio/em/em11/7.pdf
} 
DOI: $10.7256 / 1811-9018.2013 .9 .9216$

При цитировании этой статьи сноска на dоі обязательна

Человек и окружающая среда

Кроме того, сегодня уже почти ни у кого не вызывает сомнений тот факт, что реальными эмиттерами загрязняющих веществ являются не только и не столько отдельные индивиды или их домохозяйства, а сложные и разномасштабные производственные комплексы (экономические системы). Причем отдельный индивид принадлежит, как правило, к множеству экономических систем, имеющих весьма условные границы. Определить таким образом «усредненные» размеры антропогенного пресса на биосферу и ответственности за него для индивидуальных эмиттеров и даже для отдельных сообществ таковых представляется сомнительной задачей не только с этической, но и чисто технологической точки зрения. Ограничения должны относиться, прежде всего, к самим экономическим системам.

Очевидно, что только лишь путем внедрения самых передовых технологий и разного рода экономических санкций глобального антропо-экологического кризиса не избежать, но перспектива начать оперировать в культурно-идеологической подсистеме сопряжена в сознании среднего политика с серьезными трудностями и рисками.

Во-вторых, национальные научно-практические изыскания в данной области и политические стратегии зачастую довольно опосредованно связаны с глобальными исследованиями и программами. В прикладном смысле, большинство их представляют собой совокупность разнесенных по секторам проектов, не выходящих по своим функциям за пределы локального или регионального отраслевого хозяйственно-экономического менеджмента. В идеологической плоскости основная проблема состоит в том, что с 1992 года УР так и не удалось заменить собой другие «исконные» политические цели, такие как экономический рост и борьба с безработицей. В Европе, которая традиционно считается лидером в реализации концепции УР, этот приоритет обеспечения экономического роста исторически преобразовался в две конкурирующие стратегии: Лиссабонскую стратегию и собственно стратегию УР, причем первой отдается явное предпочтение в текущей политической практике ${ }^{19}$. В результате практическая реализация

\footnotetext{
${ }^{19}$ Доклад «Geo-5» «Резюме для политиков и лиц, принимающих решения» // Официальный сайт «Гражданской Двадцатки (C20)». URL: http://www.g20civil.com/upload/iblock/f65/GEO-5_SPM_Russian.pdf.
}

секторальных моделей тяготеет к традиционным парадигмам, несмотря на декларируемую в нормативных документах приверженность целям и задачам УР. В качестве примера многие исследователи приводят общественные процессы, характерные для периода после кризиса 2008 года. Призывы к коренным изменениям экономической и финансовой систем резко стихли, как только фокус сместился к цели на «экономическую перезагрузку». В итоге докризисная экономическая модель не претерпела никаких принципиальных изменений.

Попытки теоретизации данной проблемы в рамках традиционных парадигм и концепций международных отношений вряд ли способны принести какие-либо плоды в плане нахождения инновационных и действенных механизмов решения глобальных экологических проблем. Что касается объяснения текущих процессов (status quo глобальной экологической политики), то реальная международно-политическая практика обнаруживает примеры в пользу как реализма, так и либерализма и теории взаимозависимости. Аналитики часто приводят пример успешных переговоров по разрешению «озонового кризиса» 1980-х гг. как иллюстрацию применения либерального подхода в международном взаимодействии. В то время, как ситуация вокруг проблемы глобального изменения климата, по мнению ученых, свидетельствует в пользу политического реализма, главный тезис которых, как известно, состоит в том, что проблемы окружающей среды не могут быть эффективно разрешены из-за корыстных интересов государств. Относительно более перспективной и адекватной в этом смысле предстает позиция либералов. Они хотя бы признают, что сотрудничество возможно и без явного лидера, несмотря на разность интересов. Так, с точки зрения либерального институционализма, под влиянием глобальных изменений в международной жизни постепенно трансформируются сами национально-государственные интересы. Однако на практике пока только благодаря ООН существует некое подобие международно-глобального механизма согласования решений почти всех государств планеты.

Дело в том, что, несмотря на появление в международных политических декларациях (в первую очередь - «Повестке дня на XXI век») понятия «устойчивое развитие» как глобальной стратегии цивилизационного развития, которое было призвано устранить пагубную двойственность в восприятии глобальной проблематики, к сожалению, приходится констатировать, что 
DOI: 10.7256/1811-9018.2013.9.9216

При цитировании этой статьи сноска на dоі обязательна

\section{Право и политика 9 (165) • 2013}

такая двойственность все еще является доминирующей тенденцией в современной международно-политической практике в этой сфере. Как справедливо отмечает А.Д. Урсул, проявлением негативного воздействия нынешнего неустойчивого развития на процесс перехода к УР в политической плоскости является неопределенность и непоследовательность поведения основных социальных акторов этого перехода ${ }^{20}$. Красноречивой иллюстрацией этих противоречий стали итоги Конференции ООН по устойчивому развитию Рио+20. В качестве одной из основных причин этих противоречий А. Д. Урсул приводит односторонность той концепции УР, которая является объектом современных глобально-политических дискуссий, и, как следствие, очень упрощенное понимание этой концепции. В своем нынешнем, «популярном», виде она выделяет в основном экологический аспект и его связь с экономикой и социальной сферой. Отсутствие ее глубинного и комплексного восприятия порождает массу практических трудностей на пути к ее реализации.

Экологическая «ангажированность» современной концепции УР приводит к своего рода парадоксу. С одной стороны, она ставит во главу угла решение глобальных экологических проблем, с другой - решить эти проблемы никак не удается из-за мощного сопротивления ее социально-экономического «сегмента», который продолжает функционировать в рамках модели НУР. Неудивительно, что так называемая «экономика роста»и узкопрагматичные интересы в такой квазиситеме всегда побеждают. А политика УР вырождается в экологическую политику, которая вне глобальной, комплексной и системной стратегии перехода к УР, представляет собой постоянный социально-политический конфликт вокруг распределения материальных благ и международного влияния.

Наиболее перспективным, на наш взгляд, подходом к концептуальной трансформации экологической политики с целью повышения ее эффективности и ускорения глобально-цивилизационного перехода на рельсы УР является концепция «устойчивой экополитики», описанная в книге А. Д. Урсула, М. А. Мунтяна и С. Н. Бабурина «Глобализация в перспективе устойчивого развития» ${ }^{21}$. Речь идет о новом содержании

\footnotetext{
${ }^{20}$ Урсул А.Д. Контуры безопасно-устойчивого будущего: размышления после саммита РИО+20// Безопасность Евразии. М., 2012. №2(44).

${ }^{21}$ Бабурин С.Н., Мунтян М.А., Урсул А. Д. Глобализация в перспективе устойчивого развития. М., 2011.
}

экологической политики, проявляющейся в процессе глобализации и ориентирующейся на стратегию УР. Основные черты такой «устойчивой экополитики» даже в самой общей формулировке говорят о ее фундаментальном отличии от доминирующих сегодня традиционных экополитических стратегий.

В первую очередь, системность и приоритет глобальных принципов, императивов и целей по отношению к аналогичным локальным, национальным, региональным характеристикам призваны свести к безопасному минимуму (а впоследствии - устранить) конфликт глобальных и локальных факторов и тенденций. В политическом смысле это будет означать подчиненность национальных и региональных экополитических программ единой для всех планетарной стратегии развития, которая, в свою очередь, должна стать итогом глобального консенсуса, с четкими принципами и научным фундаментом. Во-вторых, соединение действий по развитию и обеспечению безопасности предполагает признание невозможности человеческого развития при деградации природной среды. Речь идет о новой концепции безопасности через устойчивое развитие, которое, при его реализации, должно характеризоваться (как минимум) экономической эффективностью, социальной справедливостью и биосферосовместимостью при общем снижении антропогенного пресса на биосферу ${ }^{22}$. В терминах государственного управления данная «формула» будет, очевидно, соответствовать взаимосвязанному и единовременному обеспечению социально-экономического развития и защиты от внешних и внутренних угроз и должна лечь в основу национальных стратегий безопасности. В-третьих, это органическое объединение в «устойчивую систему» мер по защите биосферы и рационального освоения природных ресурсов. Это, с одной стороны, повысит эффективность самой природоохранной деятельности, с другой - придаст рациональную и деятельностную форму решению экологических проблем в развивающихся странах, где упор на принятие мер по рациональному и технологичному природопользованию способствовал бы избавлению природоохранной повестки от излишней политизации. Скорее в концептуальной плоскости лежит такое требование устойчивой экополитики, как расширение принципа справедливости социальной до

\footnotetext{
${ }^{22}$ Урсул А.Д. Обеспечение национальной безопасности через приоритеты устойчивого развития// NB: Национальная безопасность. №1, 2013.
} 
DOI: 10.7256/1811-9018.2013.9.9216

При цитировании этой статьи сноска на dоі обязательна

Человек и окружающая среда

принципа социоприродной справедливости. Если бы политическим акторам в действительности удалось совершить такой мировоззренческий прорыв, это бы не только приблизило перспективу коэволюционной стратегии во взаимоотношениях человека и природы, но и понизило градус глобальной интерсоциальной напряженности. Ведь в принципе социоприродной справедливости заложен очень мощный объединительный импульс, усиливающий чувство коллективной ответственности и способный снять остроту вечного спора по поводу справедливого распределения материальных благ и равного доступа к ресурсам. В-пятых, эффективная и устойчивая экополитика предполагает активно-деятельностное участие гражданского общества (особенно транснациональных акторов) в реализации социально-экологической политики, с задействованием механизмов государственно-частного партнерства и демократических институтов. И, наконец, устойчивая экополитика должна ориентироваться на использование информации в качестве главного ресурса развития по сравнению с вещественно-энергетическими ресурсами, становясь на ноосферный интенсивно-коэволюционный путь развития.

Ответ на фундаментальный вопрос о причинах удручающей неэффективности глобальной политики в сфере УР лежит в концептуальной плоскости, а именно - принципиальной уязвимости доминирующего экологоэкономического подхода. «Традиционная» технология балансирования между экономическими приоритетами и природоохранными целями ведет к ситуации, когда экология в политической повестке попадает в полную зависимость от экономической конъюнктуры: экологическим проблемам начинает уделяться внимание лишь в периоды экономического процветания и наоборот. Именно поэтому системно-целостный подход при переходе на рельсы УР предполагает целенаправленное воздействие на каждую из трех сфер (экологию, экономику и социальную сферу), а не простую «подгонку» одних сфер под цели и задачи других.

\section{Библиография:}

1. Бабурин С.Н., Мунтян М.А., Урсул А. Д. Глобализация в перспективе устойчивого развития. М., 2011.

2. Доклад Geo-5 «Резюме для политиков и лиц, принимающих решения» // Официальный сайт
«Гражданской Двадцатки (C20)». URL: http:// www.g20civil.com/upload/iblock/f65/GEO-5_SPM_ Russian.pdf

3. Дробот Г.А. Мировая политика как феномен глобального мира: учебное пособие. М., 2010.

4. Прокофьев А. В. Климатическая справедливость: pоссийский контекст. URL: http://iph.ras.ru/uplfile/ root/biblio/em/em11/7.pdf

5. Стокгольмская Декларация// Общественный экологический Internet-проект EcoLife. URL: http://www. ecolife.org.ua/laws/inter/1972/04.php.

6. Урсул А. Д . Контуры безопасно-устойчивого будущего: размышления после саммита РИО+20// Безопасность Евразии. М., 2012. №2(44).

7. Урсул А.Д. Обеспечение национальной безопасности через приоритеты устойчивого развития// NB: Национальная безопасность. №1, 2013.

8. Чумаков А.Н. Глобализация. Контуры целостного мира: монография. - 2-е изд., перераб. и доп. М., 2009.

9. Agarwal A., Narain S. Global warming in an unequal world. New Delhi, 1991.

10. Anderson J. W. The International Politics of Sustainable Development// Resources For the Future. Washington, 2002. URL: http://www.rff.org/rff/Documents/RFFIB-02-15.pdf

11. Forsyth T. Global environmental problems and politics: Undergraduate study in Economics, Management, Finance and the Social Sciences. London, 2011.

12. Redclift M. Sustainable development: exploring the contradictions. London, 1987.

13. WCED (World Commission on Environment and Development) Our common future. URL: http://www. un-documents.net/ocf-02.htm

14. Урсул А.Д., Урсул Т.А., Ильин И.В. Глобальные и политические процессы: становление эволюционного подхода // NB: Вопросы права и политики. 2013. - 3. - C. 95 - 154. URL: http://www.e-notabene. ru/1r/article_564.html

15. А. Д. Урсул, Т. А. Урсул Глобальные исследования и становление ноосферы через устойчивое развитие // Политика и общество. - 2012. - 4. - С. $114-125$.

16. Урсул А.Д., Урсул Т.А. Глобализация в перспективе устойчивого будущего // NB: Вопросы права и политики. - 2013. - 5. - C. 1 - 63. URL: http:// www.e-notabene.ru/lr/article_794.html 
DOI: $10.7256 / 1811-9018.2013 .9 .9216$

При цитировании этой статьи сноска на dоі обязательна

\section{Право и политика $9(165) \cdot 2013$}

\section{References (transliteration):}

1. Baburin S.N., Muntyan M.A., Ursul A. D. Globalizaciya v perspektive ustoychivogo razvitiya. M., 2011.

2. Doklad Geo-5 «Rezyume dlya politikov i lic, prinimayuschih resheniya» // Oficial'nyy sayt «Grazhdanskoy Dvadcatki (C20)». URL: http://www.g20civil.com/ upload/iblock/f65/GEO-5_SPM_Russian.pdf

3. Drobot G.A. Mirovaya politika kak fenomen global'nogo mira: uchebnoe posobie. M., 2010.

4. Prokof'ev A. V. Klimaticheskaya spravedlivost': rossiyskiy kontekst. URL: http://iph.ras.ru/uplfile/root/ biblio/em/em11/7.pdf

5. Ursul A. D . Kontury bezopasno-ustoychivogo buduschego: razmyshleniya posle sammita RIO+20// Bezopasnost' Evrazii. M., 2012. №2(44).

6. Ursul A.D. Obespechenie nacional'noy bezopasnosti cherez prioritety ustoychivogo razvitiya// NB: Nacional'naya bezopasnost'. №1, 2013.

7. Chumakov A.N. Globalizaciya. Kontury celostnogo mira: monografiya. - 2-e izd., pererab. i dop. M., 2009.
8. Agarwal A., Narain S. Global warming in an unequal world. New Delhi, 1991.

9. Anderson J. W. The International Politics of Sustainable Development// Resources For the Future. Washington, 2002. URL: http://www.rff.org/rff/Documents/RFFIB-02-15.pdf

10. Forsyth T. Global environmental problems and politics: Undergraduate study in Economics, Management, Finance and the Social Sciences. London, 2011.

11. Redclift M. Sustainable development: exploring the contradictions. London, 1987.

12. Ursul A.D., Ursul T.A., Il'in I.V. Global'nye i politicheskie processy: stanovlenie evolyucionnogo podhoda // NB: Voprosy prava i politiki. -2013. -3.-C. 95-154. URL: http://www.e-notabene.ru/lr/article_564.html

13. A. D. Ursul, T. A. Ursul Global'nye issledovaniya i stanovlenie noosfery cherez ustoychivoe razvitie // Politika i obschestvo. - 2012. - 4. - C. $114-125$.

14. Ursul A.D., Ursul T.A. Globalizaciya v perspektive ustoychivogo buduschego // NB: Voprosy prava i politiki. - 2013. - 5. - C. 1 - 63. URL: http://www.e-notabene. ru/lr/article_794.html 